\title{
ARTIGOS
}

Sociologias, Porto Alegre, ano 4, № 7, jan/jun 2002, p. 188-221

\section{A polícia dos pobres: violência policial em classes populares urbanas}

\author{
EDUARDO PAES MACHADO' ECECIVLAR MOROMHA
}

Agradecemos o apoio recebido do CN Pq, entre 1995 e 1997, para a realização desta pesquisa. Estes agradecimentos são extensivos aos professores João José Reis, da U niversidade Federal da Bahia, José Vicente Tavares, da Universidade Federal do Rio Grande do Sul, e Luis Gerardo Gabaldón, da U niversidade Católica Andrés Bello, Caracas, pelos comentários e sugestões feitas ao tratamento do tema aqui desenvolvido. A primeira versão deste artigo foi publicada na revista Afro-Ásia, n. 1920, 1997, p.201-226.

\section{Introdução}

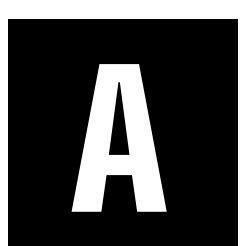

violência policial contra indivíduos e grupos, também chamada de violência oficial, é uma constante nas sociedades modernas e contemporâneas. Contudo a sua forma varia conforme o grau de tolerância, governamental ou popular, levando a que, em certos lugares, haja mais vigilância sobre a ação policial do que em outros. Assim, se em certas cidades 0 seviciamento de um indivíduo pertencente a um grupo étnico ou social discriminado é suficiente para provocar um debate público acalorado, em outras, fatos dessa ordem ou mais graves não despertam igual interesse na mídia ou na população como um todo.

Esta variação de comportamentos, da polícia e do público, remete para, pelo menos, quatro aspectos fundamentais, que são: a orientação governamental no uso da violência; a consciência de cidadania; o nível de aceitação social da violência para resolver conflitos e o padrão de relacionamento entre governo e população visando regular a cidadania e possibilitar o controle social sobre os órgãos governamentais (Chevigny, 1995).

* Professor do Departamento de Sociologia e Instituto de Saúde Coletiva da UFBA.

** Socióloga e pesquisadora do Instituto de Saúde Coletiva da UFBA. 
Pensada nesses termos, a violência oficial está ligada à violência estrutural - que se manifesta nas desigualdades sociorraciais -, mas não pode ser reduzida a esta última. O u seja, se o aparelho policial participa ativamente na manutenção e reprodução da ordem social, a forma como ele opera e trata populações pobres e não-brancas depende de controles institucionais externos e internos ao aparelho policial.

A falta desses controles contribui para que a violência estrutural se transforme em agressão direta ou interpessoal, gerando formas de vitimização e insegurança que favorecem a intolerância e servem como álibis para abusos policiais. Nestes casos, a percepção de perda de controle sobre a criminalidade faz com que setores da sociedade desenvolvam comportamentos autoritários, apoiando excessos da polícia contra responsáveis por delitos grandes ou pequenos (Chevigny, 1995).

Tais considerações se aplicam à Região M etropolitana de Salvador, Bahia, com aproximadamente 2.500 .000 habitantes, onde o padrão de policiamentos vem sendo avaliado, direta e indiretamente, por alguns estudos.

0 primeiro estudo, efetuado entre 1.000 pessoas de Salvador, revelou que, quando indagadas sobre os problemas de segurança, as pessoas destacaram a falta de policiamento (34\%), crescimento da violência (14\%), ocorrências de furtos e roubos (13\%), presença de menores abandonados nas ruas (10\%), agressões físicas ou verbais entre vizinhos (7\%), mortes (4\%) e violência policial (4\%) (Guimarães Silva, Penteado Silva, 1996).

O segundo estudo, realizado com 1.383 indivíduos, em 1996, constatou uma grande descrença popular em relação às agências de controle social - prisões, Judiciário, polícia. Somando os que avaliaram essas agências como ruins e muito ruins, a rejeição foi maior em relação às prisões (75\%), vindo em seguida o Judiciário (43\%) e, em terceiro lugar, as polícias (41\%). Q uanto ao sentimento de segurança, a maior parte dos entrevistados se sente "muito insegura" ou "insegura" quando caminha em ruas e praças (89\%), quando dirige seu carro particular (69\%) ou quando está no local de trabalho (52\%) (Noronha, Paes Machado et alii, 1997). 
Ainda de acordo com essa pesquisa, as atitudes adotadas por significativas parcelas da população não contribuem para melhorar a situação. Entre essas atitudes cabe destacar as disposições para fazer justiça com as próprias mãos (32\%), adquirir armas de fogo (21\%), aprovar invasões de domicílio sem mandato judicial (13\%) e execuções sumárias de pessoas julgadas indesejáveis (15\%) (Noronha, Paes Machado et alii, 1997).

O ra, admitindo que a violência policial decorre, em parte, da conivência da população, colocam-se indagações importantes sobre essa aprovação: Que apoio é este? Como ele se expressa na vida quotidiana dos grupos sociais? Como se coaduna com as experiências de discriminação e vitimização de populações pobres e negro-mestiças, associadas com esta mesma violência policial?

Para enfocar essas questões, apresentamos dados provenientes da observação direta ao longo de três anos, assim como de 31 (trinta e uma) entrevistas aprofundadas, realizadas, entre 1995 e 1996, com representantes de associações de moradores e outras organizações comunitárias do bairro de Novos Alagados, na área do Subúrbio Ferroviário de Salvador. Destas, 18 foram feitas com mulheres e 13 com homens. A faixa etária do grupo feminino varia de 15 a 79 anos e a do grupo masculino, de 19 a 56 anos. Para complementar essas informações, foram mantidas conversas com três oficiais da polícia militar responsáveis pela área.

Após descrever o contexto social desse bairro, muito semelhante ao de muitos outros de Salvador e outras grandes cidades brasileiras, discutimos os tipos de violência protagonizados por moradores, delinqüentes e policiais, mostrando as relações contraditórias da população com forças policiais que, sob a bandeira do combate ao crime, cometem toda sorte de abusos.

\section{U ma periferia explosiva}

A expansão urbana de Salvador nos últimos cinqüenta anos derivou do surgimento de atividades industriais que, começando pela extração e refino do petróleo, diversificaram-se com a industrialização, através de incentivos fiscais e implantação do pólo petroquímico nas décadas de 60 e 70. 
Ao mesmo tempo que a industrialização contribuiu para a criação de novas classes sociais, ela concentrou a pobreza, antes dispersa no mundo rural, no espaço da região metropolitana de Salvador, evidenciando os limites do Estado para prover a infra-estrutura urbana adequada. $\mathrm{Na}$ falta de uma política habitacional capaz de atender estas pressões, multiplicaram-se as ocupações irregulares de terras (invasões) e assentamentos precários ou favelas que, no final da década de 90 , abrigavam uma população de um pouco mais de 1 milhão de pessoas (As Favelas de Salvador, 1999).

Entre esses assentamentos, Novos Alagados, com 12.000 pessoas vivendo em uma superfície de 33 hectares, que inclui aterros e construções sobre palafitas ${ }^{1}$, está situado em uma área que se converteu em um símbolo de pobreza, degradação ambiental e violência de Salvador - o Subúrbio Ferroviário, com 41 km2 e uma população de 303.503 habitantes em 1994.

Antigo lugar de fazendas de cana-de-açúcar, passagem de trem e, posteriormente, casas de veraneio, o Subúrbio Ferroviário foi fortemente afetado pelas mudanças socioeconômicas mencionadas acima. Também aqui, a inexistência de um mercado habitacional para os pobres fez com que centenas de família iniciassem, em 1946, a ocupação de áreas alagadas e manguezais que, embora impróprias para a construção civil, apresentavam a vantagem de não serem distantes do mercado de trabalho e serem espaços públicos, sem fiscalização das autoridades responsáveis.

A formulação de um projeto de urbanização no início dos anos 70, possibilitou a realização de melhorias, mas não impediu que mais pessoas, confrontadas com os mesmos problemas e estimuladas pela expectativa de novas ações governamentais, ocupassem a Enseada do Cabrito, na borda marítima do Subúrbio Ferroviário.

A ocupação do local se realizou graças às estratégias de cooperação, transmissão de informações e participação de parentes e conhecidos nos trabalhos de aterro e construção de habitações. Essas mesmas estratégias de cooperação continuam vigorando para realizar consertos das pontes,

1 A implementação de um projeto de urbanização e habitação, a partir de 1996, relocou a população que vivia sobre habitações em palafitas, para 420 novas casas de alvenaria construídas no próprio bairro, estando previstas ainda a construção de mais 580 unidades habitacionais pelo mesmo projeto. Estas mudanças ocorridas no espaço construído, no entanto, não reduziram as ocorrências violentas na localidade. 
negociar melhorias com o Estado, emprestar mantimentos e socorrer os vizinhos em dificuldade (Paes Machado, Cardoso, 1996).

Conquanto tenham conquistado um lugar para morar, a maior parte da população não conseguiu melhorar sua posição no mercado de trabaIho. Em um dos setores da localidade, por exemplo, o de N ova Esperança, para uma população de quase 1.600 habitantes, repartida entre 400 casas, apenas $22 \%$ deles estão empregados, havendo um alto percentual de desempregados (31\%) e subempregados (22\%), assim como de menores de idade que trabalham esporadicamente (7\%) para ajudar suas famílias (Paes Machado, Cardoso, 1996).

Além do salário, as principais fontes de rendimento são biscates e 0 pequeno negócio realizado em estabelecimentos comerciais conjugados com as habitações, ou nas próprias vias de circulação do bairro. Entre as ocupações mais citadas pelos que estão trabalhando, sobressaem as atividades ligadas à construção civil para os homens e o serviço domésticos para as mulheres. Estas, por sinal, estão à frente da metade das famílias, declarando-se proprietárias das habitações e responsáveis pela manutenção do respectivo grupo doméstico.

O s moradores não têm dificuldade de associar a pobreza, falta de assistência pública e discriminação com a violência estrutural (Minayo, 1993) que incide sobre eles. Segundo Joaquim, 56 anos, negro, pastor evangélico:

A violência para mim no mundo, não é só em Plataforma [Subúrbio], é a falta de educação que as pessoas não têm, não têm formatura, não têm nada. A pessoa nasce, vive ali naquela situação, sem emprego, sem moradia, sem dinheiro.

$\mathrm{Na}$ compreensão certeira de outro entrevistado, Pedro, 20 anos, pardo, estudante, esta situação de violência social decorre das dificuldades quase insuperáveis que os moradores encontram para se inserir no mercado de trabalho metropolitano: 
Sociologias, Porto Alegre, ano 4, no 7, jan/jun 2002, p. 188-221

Porque se o cara for dizer que mora em N. Alagados... primeiro ele não tem qualificação. A maioria é de pedreiros, marceneiros, serventes... então já começa esse problema de marginalização pelas grandes empresas.

A triste fama do local, denominado de "Baixada Fluminense" pelos meios de comunicação, está associada aos altos coeficientes de crimes contra a pessoa (76,6/10.000 habitantes), homicídios (46/100.000 habitantes) e lesões corporais (305,44 por 10.000), em 1991 (CEDEC, 1997).

Com níveis de violência que superam os de Salvador, o bairro atemoriza seus próprios habitantes, como está dito nas palavras de Claúdio, 22 anos, negro, professor primário: A violência aqui sempre foi assim triste, sempre foi assim... tinha noite da gente nem conseguir dormir por causa dos tiros e de tanta morte que teve... a gente não tinha paz. Q uer dizer, eu não me sinto em paz ainda.

A violência que brota das desigualdades sociais e se manifesta nas ocorrências diárias remete para regras e condutas que favorecem agressões interpessoais e complicam a socialização das novas gerações.

\section{A violência nas famílias}

Conquanto as atribuições de responsabilidade pela violência interpessoal se concentrem nos "marginais" e policiais, a família e a vizinhança não constituem instâncias isentas de agressões. Ao lado de valores como solidariedade e amizade, que ajudam a resolver dificuldades práticas e contribuem para criar sentimentos de identidade, a violência projeta a sua sombra sobre a vida social.

A aceitação da agressão, como ameaça e uso da força, remete para a fragilidade das concepções e práticas de negociação de conflitos, em nível dos direitos costumeiro e formalizado. Expressando uma separação entre sociedade e poder político estatal, essa fragilidade dos mecanismos de regulação de conflitos é causa e conseqüência de uma sociabilidade funda- 
da em soluções de tipo pessoal, que promovem a integração social, mas dificultam a resolução pacífica de disputas (Carvalho Franco, 1983). Essa fragilidade das instituições do direito assume conotações específicas no caso de segmentos populares com menos acesso às agências estatais, relações contratuais e outras instâncias que asseguram reconhecimento, favorecem a aprendizagem dos direitos (e deveres) e o exercício da reclamação.

Se, no processo civilizador, os indivíduos e grupos são levados, por diferentes códigos de comportamento, a estabelecer controle sobre suas emoções agressivas (Elias, 1994), nas situações de exclusão social este processo é paralisado (Chevigny, 1995). Em lugar de uma reversão das emoções agressivas, o que se tem é uma persistência de valores que cultuam a força como meio de agressão ou defesa.

Em contraste com a cultura da agressão (Gay, 1995) das camadas sociais altas e médias, que se valem mais da intriga, desgaste pessoal e perseguição política para tratar das desavenças, as pessoas nas camadas populares são interpeladas a empregar a força física - "porrada", "cacete" e "pau" - para revidar as ofensas recebidas. Se a ofensa atenta contra a honra ("consideração") de cada um, só a "porrada" pode anular o rebaixamento e resgatar a honra ("lavar a alma") do ofendido.

Esta valorização da força está presente no encaminhamento de conflitos que envolvem aspectos como: papéis familiares, desemprego, forma de habitação, consumo de álcool, separações conjugais e socialização dos filhos.

Em meio a conflitos familiares que resultam em agressões, identificase uma linha de tensão entre os papéis masculino e feminino no tocante aos engajamentos afetivo-matrimoniais e familiares. Aqui, como em outros setores da sociedade, o homem procura compensações sexuais sem maiores compromissos, enquanto a mulher, ainda que freqüentemente faça este jogo, busca situações mais estáveis. Tais demandas contraditórias, que estão na base de uma grande flutuação nas relações sexuais e maritais, são intensificadas pelas condições de vida. 
O desemprego contribui para a instabilidade das relações familiares, limitando as prerrogativas masculinas ligadas aos papéis de marido, provedor e socializador da prole. 0 desemprego golpeia a autoridade masculina, reduzindo o prestígio do homem em relação à mulher que, embora também seja afetada por ele, não sofre os mesmos impactos negativos. Além de a mulher estar menos identificada com a responsabilidade econômica, ela aceita trabalhos menos valorizados e, qualquer que seja a situação econômica do grupo, está investida de uma importância ritual, prática e afetiva maior do que a figura do pai. Conseqüentemente, surgem conflitos entre a autoridade reivindicada e a autoridade exercida pelos componentes adultos da família, como veremos abaixo.

O tamanho reduzido das habitações favorece a sobreposição de papéis, sobretudo no caso de famílias extensas, nas quais casais jovens e mulheres separadas são obrigados a morar com os pais. Conquanto esta situação tenha suas vantagens - a economia do aluguel, partilha dos gêneros alimentícios e dos cuidados com as crianças pequenas -, ela costuma gerar conflitos, fazendo com que a agressão se desenvolva como um meio de possibilitar a separação de papéis e individualização ( $D$ aMatta, 1993) dos membros da família. Tal situação foi sintetizada por Pedro do seguinte modo:

O casal não tem onde morar, não é? Mora junto com os pais... então fica essa chatice, você não gosta de trabaIhar, você casou com minha filha, porque você não faz isto, aí começa aquela discussão, aí um começa a querer matar o outro... por causa disso, não tem onde morar.

Confrontados com essas dificuldades, muitos pais de família perdem a auto-estima, entregando-se à ociosidade ou ao "desespero" de não poder sustentar a família e adotando posturas compensatórias como 0 alcoolismo, que estimulam agressões. 
A bebida, que promove a camaradagem entre os vizinhos, transforma-se em um refúgio para os pais de família desempregados, facilitando a perda de controle sobre emoções negativas em relação a um quotidiano insatisfatório, no qual os indivíduos se vêem negados. Associada ao valor moral da força física, a ingestão de bebidas é aprendida muito cedo e, ainda que o grupo identifique uma relação entre álcool e agressão, não constitui objeto de maiores sanções sociais, como acontece com a maconha, que estigmatiza os usuários. Este papel negativo da bebida foi descrito por Isabel, 52 anos, negra, professora primária, nos seguintes termos:

0 que acontece muito aqui é briga de casa, o pai com a mãe e os filhos também, porque eles chegam bêbados em casa e não tem nada, não tem alimento, [aí] eles só vão mesmo é ficarem desesperados. Aí começa a briga.

Q uando desentendimentos entre casais se convertem em separações, seguem disputas violentas em torno das responsabilidades pessoais e divisão dos escassos bens acumulados. $\mathrm{Na}$ falta de sanções morais e mediações institucionais, o par resolve as disputas através de ofensas, espancamentos, ferimentos e destruição de barracos e utensílios domésticos. Como a maior parte dos conflitos, as brigas familiares provocam a intervenção de vizinhos para conciliar e até salvar as vidas de maridos e esposas, como aconteceu em uma situação narrada por Clara, 21 anos, negra, vendedora ambulante:

Tem um rapaz que mora aí que só vive brigando, aí tem vez que eu vou lá tirar [apaziguar], tem até uma que está de barriga... aí briga, discute, dá chute na barriga, pronto começa a brigar... dia mesmo um colega que estava aqui, foi lá tirar a briga.

Nestas circunstâncias, a socialização dos filhos oscila entre os pólos da permissividade e da repressão. A falta de limites se expressa na atitude de não acompanhar o comportamento dos filhos. Como conseqüência do envolvimento dos pais na tarefa de sobreviver, da ausência do pai e sobre- 
carga das mães, os filhos ficam muito tempo sozinhos ou entregues aos cuidados de irmãos, um pouco mais velhos do que eles, ou pessoas idosas que não estão preparadas para assumir este encargo.

Entregues a si mesmas, as crianças fazem brincadeiras que motivam desentendimentos entre moradores em torno da autoridade para aplicar punições nos menores. Dada a precariedade do espaço físico, as crianças invadem o espaço do outro, danificam o espaço comum e, tal como os pais, não aceitam reclamações dos vizinhos. Por sua vez, estes acabam tomando as suas próprias medidas contra os filhos alheios, como ameaças, beliscões, puxões de orelha e outros castigos físicos que, ao chegarem ao conhecimento dos familiares, provocam brigas entre adultos, que exigem a intervenção da polícia para restabelecer a paz.

Esta falta de acompanhamento dos filhos se torna mais aguda no momento que estes entram na escola e precisam dos pais para enfrentar as dificuldades da aprendizagem. Por conta dos problemas de sobrevivência, as famílias colocam seus filhos menores para fazer trabalhos esporádicos, 0 que compromete a permanência destes na escola e torna as crianças mais expostas à chamada cultura de rua. Como a maior parte desses trabalhos é efetuado nos espaços públicos ou de circulação, as crianças entram em contato com personagens do submundo urbano, vagabundos, delinqüentes e agenciadores do crime, sofrem agressões de terceiros e iniciam a aprendizagem de condutas infratoras.

A falta de controle é maior naquelas situações em que a instabilidade familiar e o desemprego minam a autoridade parental sobre os filhos, que não aceitam ser reclamados e fazem uso da violência contra os pais, como foi dito por Pedro:

O s jovens não respeitam muito o pai, respeitam mais a mãe. Eles dizem assim, meu pai é isto e não vou respeitar ele não. 0 pai quando vai bater nele, ele mete logo a madeira. A mãe tem muita autoridade sobre eles. Ele faz 
assim, se acontecer alguma coisa é minha mãe que vai tirar então pronto, eles respeitam mais... sempre também tem aquela conversa, ah! meu pai não fez nada por mim, minha mãe é que faz.

Para conjurar estas situações, muitos pais empregam a violência dos espancamentos ou "surras" para mostrar que eles não abrem mão da sua autoridade. Este aspecto repressivo da socialização se torna mais crítico devido às notícias sobre jovens que, provenientes de famílias "direitas", se envolveram com "marginais". Tais notícias aumentam a desconfiança entre pais e filhos, gerando situações de tensão entre uns e outros, nas quais gestos banais e atitudes contornáveis dos filhos são tomados como provas de "descaramento" ou "falta de vergonha", o que justifica novos excessos físicos e verbais. Parece haver um consenso de que se o jovem não tiver uma educação que inclua vigilância e surras, ele irá envolver-se com "gente ruim", com o que "não presta", com a criminalidade.

Em muitos casos, esses modelos de socialização, combinados com as ansiedades coletivas a respeito dos jovens, criam um clima favorável para que estes não aceitem conselhos, façam uso da violência - contra familiares, vizinhos e outros jovens - e adotem condutas censuradas pelo grupo, como andar com "más companhias", usar drogas e ingressar na "marginalidade".

Estas dificuldades de lidar com conflitos quotidianos e de oferecer modelos positivos para as novas gerações se refletem também na impotência dos habitantes para conter os atos de jovens infratores.

\section{M oradores e marginais}

Apesar de os moradores de áreas periféricas urbanas como Novos Alagados estarem habituados ao recurso da agressão para resolver muitos conflitos, a atuação de marginais extrapola os limites do aceitável, gerando reações que remetem para a imagem dos infratores. Segundo Pedro: A gente chama de marginal aquele cara que gosta de bagunçar, aí vai roubar 
relógio [e] estas coisas assim (...) marginal chega assim, vai logo metendo revólver em sua cabeça e você fica logo sem saída, vai ter que dar mesmo.

Agindo individualmente ou em grupo, eles dispõem de um poder de retaliação, de vida e morte, que subverte as relações sociais, fundadas sobre critérios de idade, força física e ocupação, e tira o controle dos moradores sobre o espaço do bairro. Este poder está retratado na seguinte declaração de Sara, 22 anos, parda, estudante: O ladrão vive do lado de fora e nós vivemos dentro de casa. Porque? Vivemos com medo. Saímos com medo. Em tempo de ser assaltados ou até mortos como às vezes acontece mesmo.

A existência e a razão das "ovelhas desgarradas" do grupo, os que usam a força para impor a vontade ou anular a capacidade de reação do outro, estão registradas no relato de Claúdio enfocando o ingresso dos jovens na marginalidade:

Necessidade de ter as coisas... porque é terrível você ir para a escola e ver que seu colega tem um bocado de coisas que você não tem. Tem uma bermuda boa, um tênis bom que você não tem. Porque? Então essa é uma das causas... que não justifica. A falta de emprego... de oportunidade de vida que você não tem. Aqui não tem. Ou você fica aí nas ruas ou você sei lá... não tem oportunidade de ter as coisas... As camaradagens... se seus camaradas são, dificilmente você não vai ser. Porque? Porque se você tem aquele grupo... é como se o que é de um passasse a ser de todos (...) E as meninas se tornam mulher de vagabundo... Então juntam o útil ao agradável, digamos assim, e hoje são marginais.

A falta de perspectivas profissionais, o sentimento de privação dos jovens e a influência de outros jovens iniciados na marginalidade desembocam em um individualismo absoluto ou explosivo (Castel, 1995). Tal influência é proporcional ao fascínio exercido por marginais que alcançaram uma certa notoriedade, sobre crianças e jovens. Ainda de acordo com Claúdio: 
Os modelos daqui eram assim... Carlinhos Tipofe era 0 grande modelo da gente... porque [era] um justiceiro... o cara tinha uma arma... E as lendas que se contam deles... são maravilhosas... de contar assim que eles saíam dando dinheiro na rua... pagava cerveja para todo mundo... e isso fascinava todo mundo (...) E a gente cresceu muito assim com esses modelos (...) Ser marginal sempre foi a grande sensação. Você adquirir respeito... adquirir... sei lá, de se envolver nas coisas, de mudar as coisas. Fazer coisas que uma pessoa normal não faz. Você adquirir uma áurea de superhomem, não é? Você passar por tantos... não levar uma bala... sair ileso. Ah! quando um marginal se jogava na maré [para escapar da polícia] a gente sabia tudo no lugar. 'Vai conseguir. Vai conseguir'. E tinha um heroísmo nisso. Tinha um lado lúdico nisso... e era muito por isso.

Com estes motivos de identificação, muitos jovens do bairro e áreas adjacentes demonstram disposição para ingressar em "bandos" ou quadrilhas de malfeitores. Criados a partir da iniciativa de um jovem determinado, os bandos se ampliam com 0 ingresso de membros atraídos por suas atividades. A camaradagem entre jovens - rapazes e moças -, o consumo de drogas, maconha e inalantes químicos, e o uso de gíria contribuem para criar um estilo de comportamento transgressivo e estigmatizado pelos vizinhos. A iniciação na delinqüência acontece através de extorsões, furtos e roubos no bairro ou fora deste. Estas ações servem para provar a coragem individual, fortalecer a identidade do grupo e obter algum dinheiro para necessidades imediatas, aumentando o prestígio dos indivíduos junto ao grupo de pares e meninas do lugar.

Os contatos entre lideranças (ou cabeças) e agenciadores que lucram com o crime - bandidos experientes, receptadores de mercadorias roubadas e policiais infratores -, proporcionam armas de fogo e informações sobre locais favoráveis para realizar ações ousadas ou "pesadas", os assaltos a mão armada (Paes Machado, Tapparelli, 1996). Com isso, o bando adquire uma visibilidade ou "fama" que tem efeitos contraditórios nas relações com os habitantes. 
0 aumento da visibilidade do bando pode levar a pactos de nãoagressão ou a atos de beligerância contra os moradores. Se, no primeiro caso, eles conseguem a neutralidade e a simpatia de pessoas, no caso do confronto, quando os marginais "sujam" o território, eles alienam o apoio e ficam mais expostos às queixas e denúncias dos moradores. $N$ ão sendo mutuamente excludentes, uma vez que os pactos costumam revelar-se provisórios, estas condutas suscitam reações entre os moradores que são, por ordem de importância, o medo de ser roubado, a política de boa vizinhança e a tomada de precauções.

Facilmente compreensível, o medo de ser roubado associa a perda de valores logrados com a venda da força de trabalho, essenciais para 0 sustento da família, com a violência sofrida, a impotência para revidar e 0 ressentimento contra os agressores. Conforme o depoimento de 0 scar, 52 anos, negro, eletricista, Você vai trabalhar para ter seu pão, seu trocado ... chega para dar aos seus filhos ... chega um aí e lhe toma. Então nessa hora a pessoa perde a cabeça [controle] e se puder dar fim naquele, então uma coisa dá na outra ... então se você puder matar não morra.

A política de boa vizinhança visa neutralizar ou angariar a boa vontade dos chamados "donos da rua" (Paes Machado, Tapparelli, 1996). Procurando equilibrar proximidade e distância, a boa vizinhança inclui comportamentos que vão da troca de cumprimentos até a concordância com o pagamento de extorsões, em dinheiro e em espécie, como meio de não ser vitimizado. As relações pessoais com as lideranças também são importantes para obter reparos de ofensas, reaver valores roubadose, até mesmo, poder receber visitantes externos ao bairro. Em meio a essas estratégias, existem pessoas que se tornam cúmplices dos infratores, prestando serviços, obtendo favores e receptando bens roubados. Não sendo suficiente para proporcionar segurança, a diplomacia precisa ser acompanhada de outras medidas.

As medidas de precaução estão direcionadas tanto para evitar a ação dos ladrões - não carregar objetos de valor, andar em grupo, evitar circular em locais e horários julgados mais perigosos e buscar proteger as casas -, 
como para se prevenir da polícia que, ao interpretar tal ou qual gesto de boa vontade dos moradores como "acobertamento" de marginais, pode retaliá-los.

Confrontados com essas dificuldades de relacionamento com a marginalidade, não é de estranhar que moradores elaborem três interpretações acerca do significado maligno para a coletividade: a naturalização, a demonização e a culpabilização.

A naturalização da conduta desviante é parte de um senso comum que explica os comportamentos a partir de fatores inatos, predisposições herdadas ou fatalidades do destino, que independem do arbítrio individual e das pressões sociais. M uito influente nas teorias criminológicas de todas as épocas, a visão do marginal como anomalia da natureza denega as responsabilidades, apazigua as consciências e endossa medidas drásticas contra os desviantes.

$N$ a visão demonológica, o delinqüente é o mal absoluto, a encarnação do diabo que, impulsionado pelo egoísmo, rompeu com a ordem do mundo. A luta do bem e do mal se reatualiza na escolha dos indivíduos por um ou por outro, como é colocado por Sara, para quem:

A pessoa tem um filho. Será que aquele filho nasce ladrão? N ão nasce. Q uando a pessoa cresce... o egoísmo, 0 desejo vai fazer daquela pessoa um ladrão. A mesma coisa é o diabo. Deus não fez o diabo. Ele mesmo se tornou pelo egoísmo. Ele queria ter riquezas, então hoje tem muitas pessoas que fazem pacto como o diabo.

Ambas as visões são coerentes com a transformação do marginal em bode expiatório. Exacerbando o elemento condenatório das outras interpretações, a figura do bode expiatório nomeia ameaças, unifica visões conflitantes e parece oferecer uma saída para a crise social. Mais do que as outras, esta interpretação contribui para aumentar o isolamento dos marginais e justificar ações drásticas contra eles. As palavras de Cristina, 51 
anos, parda, lavadeira, mostram a relação entre essa visão e as atitudes sociais de pessoas como ela, que estão inclinadas a defender a pena de morte para os marginais: Eu acho assim: devia ter pena de morte, para quando eles [os marginais] fazerem perversidade também morrerem. Porque estão matando gente demais.

Concentrando a culpa nos marginais, a população termina legitimando, como vamos mostrar, a brutalidade policial.

\section{Forças policiais}

A polícia está organizada sobre bases estaduais e se subdivide em dois ramos independentes: a polícia militar (PM) de caráter ostensivo e a polícia civil, dedicada a atividades investigativas. Embora diferenciados, ambos os ramos da polícia estão voltados para a manutenção e reprodução de uma ordem social desigual e hierárquica, concentrando a repressão nos escalões inferiores da sociedade.

Conseqüentemente, a distribuição dos serviços policiais, em termos de efetivos e equipamentos, acompanha os níveis de renda e prestígio das diferentes subáreas da cidade. As evidências disso se expressam nos coeficientes de alocação dos policiais entre áreas de classe alta e média, nas quais a relação é de 1 policial militar para cada 150 moradores, e áreas pobres, nas quais a mesma relação se eleva para 1 policial para 2.272 habitantes. Incluído entre estas últimas áreas, o Subúrbio Ferroviário detém uma proporção de 1/1.045 e dispõe de apenas três viaturas.

Se, entre os policiais militares, ocorre essa discrepância entre áreas residenciais ricas e pobres, algo bem parecido se dá na distribuição dos recursos da polícia civil. No plano estadual, os comandantes calculam que a relação é de 1 policial civil para cada 2.900 habitantes. Enquanto isso, a 5a Delegacia da Polícia Civil, que atende ao Subúrbio Ferroviário, funciona em um prédio mal conservado e dispõe apenas de duas viaturas. 
Isso posto, a população menciona aspectos que ajudam a entender os modos de atuação dos policiais do $18^{\circ}$ Batalhão da PM e da $5^{\text {a }}$ Delegacia da Polícia Civil que servem o bairro. A primeira se faz presente através de dois postos (São Bartolomeu e N. Alagados), com 12 homens que se alternam diariamente, e de comandos policiais fortemente armados e motorizados, formados por 3 ou mais homens, que fazem expedições periódicas à busca de marginais. A polícia civil, por sua vez, embora não tenha equipamentos semelhantes aos módulos da PM , tem uma capilaridade maior do que esta, por recorrer mais aos serviços de informantes, também denominados de P2 ou X9, para organizar suas próprias expedições repressivas. Além destas formas de trabalho policial, deve-se atentar para a atuação de grupos de extermínio integrados por indivíduos chamados de "encapuzados", pelo fato de usarem capuzes e máscaras para esconderem sua fisionomia.

Entre as duas polícias, os moradores demonstram mais simpatia pela civil. A PM é vista com mais desconfiança pelo método mais padronizado de trabalho, pela maior impessoalidade e uso ostensivo da força em operações "pesadas". O s PMs usam farda e corte de cabelo militar, exibem armas pesadas, andam em bandos e se deslocam em carros oficiais. São descritos ora como arrogantes, quando fazem demonstração de força e desrespeitam os habitantes, ora como ineptos, por não serem capazes de reconhecer e tomar medidas enérgicas contra os marginais.

Tal como a PM, a Polícia Civil é considerada violenta, mas em contraste com a primeira, a sua maneira é mais do agrado dos moradores. Sendo menos freqüente a rotatividade dos efetivos que integram suas expedições, moradores estabelecem familiaridade com os policiais e podem, desta forma, exercer alguma influência sobre as ações destes. Por outro lado, essa polícia tem uma forma de agir mais seletiva e direcionada aos suspeitos, e suas ações não parecem assumir o caráter espetacular imputado aos PMs. Assim, os policiais civis são retratados como cidadãos "comuns" na aparência e nos modos de proceder às ações repressivas. U sam 
roupas e cortes de cabelo comuns, se deslocam em carros comuns e conhecem os moradores. Tendo mais conhecimento da área, os policiais civis possuem referências precisas das pessoas que estão procurando e dos locais onde encontrá-las. Cometem menos erros quanto a confundir 0 morador pacato com um fora-da-lei.

Ambas as polícias obtêm informações sobre as atividades dos marginais através de moradores e, mais freqüentemente, de outros marginais. Em um meio social como este, onde todos se conhecem, e as relações pessoais constituem um recurso valioso, estabelecem-se facilmente laços de cumplicidade por meio dos quais são transmitidas e barganhadas informações que facilitam a identificação dos "bandidos". No entanto, respeitando a chamada "lei do silêncio", que preserva a autoria dos crimes e a vida de quem sabe, os moradores só dão informações quando estão sob ameaça dos marginais ou são fortemente pressionados pela polícia.

A maior fonte de informação são os próprios marginais, que delatam ("entregam") os comparsas, por terem sido forçados pela polícia ou por livre vontade, para tirar vantagens pessoais. Levando em conta o pouco senso de solidariedade e hierarquia entre os membros das quadrilhas (Zaluar, 1994), estas se convertem em verdadeiras armadilhas para os marginais que, além de correrem riscos nos assaltos e confrontos com outros marginais, estão sujeitos a delações de companheiros que se tornam colaboradores da polícia.

As operações policiais (ou parapoliciais) de caça aos marginais acontecem, no dizer dos moradores, em "fases". Trata-se de um termo que serve para conotar uma ação repressiva periódica que, acompanhando os movimentos das quadrilhas, intercalam momentos de trégua com momentos de guerra. Este ciclo parece ter uma variação sazonal, tendo como ponto máximo de repressão as festas populares do meio e do final do ano, quando os marginais intensificam os roubos e assaltos, visando obter dinheiro e participar dos festejos. 
$\mathrm{Na}$ fase de pressão contra os marginais, são organizadas operações, rápidas ou demoradas (de até uma semana), que compreendem o cerco da área, bloqueio de vias de circulação, invasões domiciliares, tiroteios, prisões e mortes. Embora a polícia tome alguns cuidados como avisar aos moradores para estes não circularem nas vias públicas, o terror é um componente obrigatório das operações.

Conquanto os grupos de extermínio não façam parte da organização policial estrito senso, os numerosos indícios sobre a participação de policiais e a impunidade desses grupos, evidenciam uma complementariedade entre a ação deles e a da polícia. As evidências apontam para a associação entre policiais, ex-policiais e matadores de aluguel, para venderem serviços a comerciantes (e outros particulares) dispostos a pagar para se verem livres de desafetos que podem ser tanto cidadãos comuns quanto infratores. Como o custo de uma morte destas fica em torno de mil reais, podese imaginar que elas constituem um negócio rentável para muita gente envolvida nesses grupos.

Estas características violentas do aparelho policial geram reações ambivalentes, que expressam a dificuldade da população em se posicionar diante de uma força que também é percebida como garantia de proteção. Mas, neste "mundo cão" o limite entre ser protetor e agressor é mínimo.

\section{Povo contra polícia}

Dada a soma de violências existente e o sentimento de insegurança despertado por elas, os moradores se voltam para a polícia como a instância que deveria protegê-los das agressões praticadas pelos vizinhos e, principalmente, pelos marginais. Em lugar disso, a ação policial está pautada na omissão, cumplicidade com infratores, preconceito e violência.

A expectativa popular é de que a polícia se configure como um serviço extensivo, que cubra o bairro como um todo, e intensivo durante a 
noite, em especial, a madrugada, um horário de deslocamento para os trabalhadores ali residentes e de atuação dos marginais. Para os inseguros moradores do lugar, assim como para outros segmentos da população, só o policiamento efetivo pode proporcionar segurança, impondo "respeito", e reduzir o controle dos marginais sobre os espaços comuns.

Dada a falta de policiais para fazer rondas, atender chamados urgentes e apurar crimes, essa aspiração está longe de ser atendida. Assim, segundo avaliação de Rosa, 72 anos, parda, doméstica:

A polícia aqui no bairro eu não sei o que anda fazendo (...) Tem um posto lá na frente... mas estão resguardados lá... e cá o movimento como é que fica? Eu acho que era muito bom que a polícia andasse nos lugares mais arriscados. Porque o nosso bairrozinho por causa do risco é demais (...) É por isso que se dão as coisas e quando a polícia vem dar fé... já passou o tempo! Não dá nem mais tempo de dar jeito.

Em contraste com outras áreas da cidade, onde moradores abonados e órgãos públicos dispõem de recursos para contratar serviços privados de segurança e fazer convênios com a polícia, o padrão de policiamento de Novos Alagados não oferece segurança. Assim, na percepção de Claúdio os policiais deveriam fazer aqui como eles fazem em outros bairros. Eles dão segurança. Aqui não, eles dão insegurança.

Ainda que o depoimento idealize o serviço policial prestado aos moradores dos bairros de classe alta e média, que tem seus próprios problemas de segurança, o mesmo depoimento chama atenção para o fato de a polícia cometer menos abusos contra residentes aqueles do que contra moradores das áreas urbanas periféricas, que não têm meios de reclamar ou serem ouvidos pelas autoridades (Gabaldón, Birbeck, 2000).

Esta crítica é alimentada pela falta de sigilo e suspeitas de colaboração com o crime por parte dos agentes públicos. 0 fato de a polícia não manter sigilo sobre denunciantes, expõe os mesmos a retaliações, refor- 
çando a "lei do silêncio" e enfraquecendo mecanismos de controle social que deveriam ser estimulados como parte de um modelo efetivo de policiamento. Este é o sentido do depoimento de Luiza, 38 anos, negra, professora primária, ao afirmar que:

Outro dia uma mulher informou para a polícia onde a quadrilha estava fumando [maconha]... na mesma hora a polícia chegou e disse: 'foi a mulher de toalha que falou'. Aí ela ficou mal vista. Eles não deviam ter dito isso. Quando não dá uma informação eles xingam, esculhambam... e quando informa eles entregam. Como é que a gente vai ajudar a polícia? Não pode porque ela não dá segurança nenhuma(...) E agora mesmo a gente nem pode falar, está se dando um caso muito grave, eu tenho até medo de falar porque aqui se você não fala está seguro, se fala pode levar um tiro... Agora tem aqui uma quadrilha que quem está ajudando é a própria polícia(...) E não é só esse caso não, tem vários e vários.

Com respeito às suspeitas de colaboração da polícia com o crime, as evidências gerais, difundidas nos meios de comunicação, e específicas para o bairro, mostram que os habitantes não estão equivocados. Existem policiais que, visando extrair vantagens pessoais do crime e extorquir os infratores, demonstram tolerância, mantêm cumplicidade e incentivam infrações destes, até o momento em que, sentindo-se ameaçados por marginais que reclamam do montante das extorsões ou sabem demais, resolvem eliminá-los através de ações conhecidas como "queima de arquivos". Essas suspeitas de cumplicidade ou "trama" entre policiais e infratores estão no relato de Cristina:

Não sei qual é o caso das polícias não. Vejo a conversa [que] quando pega um inocente e bate, bate tanto que deixa aleijado de porrada e quando pega um que é viciado faz [de conta] que tá batendo e depois solta para 
Sociologias, Porto Alegre, ano 4, no 7, jan/jun 2002, p. 188-221

tornar roubar(...) Aí pronto ninguém sabe não é, por isso nego [as pessoas] diz que essas polícias parecem que tem alguma coisa tramada assim com esses vagabundos. $\mathrm{Nin}-$ guém sabe quem é o certo(...) eu acho que é combinado os dois. Porque se ali é da polícia mesmo dava uma lei, um exemplo, prendia, prendia para nunca mais ser solto.

Q uanto a esses e outros abusos de autoridade, os moradores vêem os mesmos como expressões da discriminação contra eles (Pinheiro, 1983). Assim, mesmo que a maioria dos soldados venha da parte excluída da sociedade, eles absorvem esquemas discriminatórios e desenvolvem condutas violentas contra pobres e não-brancos. Estes por sua vez, como não dispõem de recursos materiais e políticos para modificar a imagem produzida sobre eles, nem para agir contra os abusos, constituem presas fáceis para a violência policial.

Este tratamento recebido pelos habitantes das áreas periféricas foi comentado por Tiago, 42 anos, negro, digitador, da seguinte maneira: A discriminação da polícia com as pessoas que moram em Alagados ou invasão é grande. Porque quando ela entra, ela não respeita ninguém. Esta também é a avaliação de Juvenal, 48 anos, negro, líder comunitário, ao declarar que a polícia mesma quando chega na Barra ou na Graça [bairros de classe média] trata os marginais de doutor... mas se 0 doutor estiver aqui eles vão tratar como marginal... E eles costumam dizer que aqui só mora marginal.

Em N ovos Alagados, onde existem muitas casas e barracos construídos sobre terrenos pantanosos, um dos estigmas identifica os moradores com caranguejos que vivem na lama e que, estando desprovidos de humanidade, não possuem direitos. Assim, moradores como 0 svaldo, 33 anos, pardo, professor de capoeira, queixam-se da crueldade da parte de policiais como os que ofenderam e espancaram um rapaz: Você é caranguejo que mora na maré, na ponte; aí me botou no camburão [caminhonete]... e começou a me bater, bater. 
Tanto a agressão motivada pela "aparência pessoal", como a resistência do grupo ao uso da força policial, podem ser verificadas em um relato que trata da violência praticada contra um negro que usava cabelo identificado com a afirmação racial. 0 comentário é de um outro jovem negro, o professor primário Claúdio, já citado outras vezes:

Ele [policial] tem essas tendências... uma vez pegou um rastafari e foi arrastando pelos cabelos, pensando que era ladrão. Aí foi um bocado de gente da comunidade para o módulo, ficou fazendo arruaça. Aí ele pegou e libertou... Ele tem essa mania... você tem que andar como granfino... sapato tal... para não ser confundido com um ladrão. Você pode até não ser, mas se tiver cara... eles oh! Agora a gente fica sem saber o que é cara de marginal [e] o que não é. É uma situação muito insegura.

Abordando a agressão sofrida por um rastafari, o morador questiona o sistema de rastreio da polícia que, em uma cidade formada majoritariamente por pobres e não-brancos, continua tomando a negritude como 0 principal critério de suspeição. Baseando-se neste critério, a repressão policial atinge fundamentalmente negro-mestiços pobres, e, às vezes, nem tão pobres, que se encaixam no estigma. No caso das pessoas identificadas com a afirmação racial, que portam sinais distintivos, como roupas e cabelos étnicos, essa repressão pode apresentar-se tão ou mais cruel do que em relação a outras. Recentemente, houve o caso de um líder sindical que teve seu cabelo rastafari cortado em praça pública pela polícia, durante uma manifestação de servidores públicos na cidade.

Ainda que não poupem mulheres e pessoas idosas, os abusos recaem principalmente sobre a rapaziada negro-mestiça do bairro periférico que, vista como mais perigosa, é freqüentemente abordada, revistada e espancada. 0 fato de os rapazes não poderem reagir facilita a punição antecipada, o bater antes de indagar e o traumatizar os corpos para neles inscrever o medo. Procurando descrever a violência contra os jovens, Paulo, 25 anos, branco, locutor de rádio, fez o seguinte relato: 
Sociologias, Porto Alegre, ano 4, no 7, jan/jun 2002, p. 188-221

A gente está aqui no bairro [e] chega um cara sem nenhuma formação de relações humanas, dando tiros a torto e a direito. Então a gente não pode confiar na polícia porque [os policiais] são violentos, são marginais, se aproveitam da farda até a paisana... eles pegam aqui os meninos de Novos Alagados e batem, dão coronhada de revólver, dão murro, dão bicuda... e até pelo fato deles serem polícia não vão revidar. A agressão da polícia aqui no bairro é muito freqüente.

As ações policiais de revista e averiguação, acompanhadas por ofensas, pancadaria, exibição de armas e tiroteio, representam uma afronta para os moradores, negando a imagem que estes têm de si mesmos como pessoas direitas, trabalhadores honestos e pais de família, que não se identificam com os fora-da-lei. Abordando esta situação Tiago declarou:

Eu não estou dentro da cabeça da polícia. Não querendo falar demais, certa vez nós estávamos aqui, quatro pais de família jogando dominó. Aí eles [a polícia] chegaram abordando a gente de noite, a gente teve que levantar, botar a mão na cabeça. E eles apontando aquelas armas ali para a gente(...) seja lá quem for, nós temos nossos direitos... tá entendendo?

Ora, igualando moradores e marginais, a polícia acaba sendo identificada com os bandidos que, como ela, também não respeitam 0 direito do outro e usam a força para impor a sua vontade. Esta é a visão da professora primária Luiza ao dizer que quando dá 6 horas da tarde ninguém pode sair mais de dentro de casa ... quando não são os marginais é a polícia. Avaliando a periculosidade da polícia Luiza acrescenta que esta:

Q uando chega quer que a gente dê conta, quer que fale, você não sabe mas é obrigado a falar e dizer onde está... apanha... é xingado... eu acho que a polícia aqui faz mais medo do que os marginais. 
Não é sem razão que, borrados os limites entre legalidade e ilegalidade, os moradores empreguem as mesmas expressões, "estrago" e "pegou o que não deixou", para se referir à atuação de policiais e marginais.

0 risco é maior quando o bairro é transformado em praça de guerra e a polícia dispara armas de fogo contra marginais abrigados nas casas, sem se preocupar com a segurança dos habitantes, como foi dito por Sara:

Essa semana teve um assalto na barraca e os ladrões correram para cá. $\mathrm{Na}$ casa que eles acharam aberta eles entraram. Então a polícia veio atrás, foi atirando sem saber quem estava na frente. No ano passado teve um rapaz mesmo que morreu. Todo mundo aqui teve de ficar de porta fechada porque a polícia foi atrás e acabou matando ele dentro da maré. Se tem uma criança na frente passando... é capaz de tomar um tiro.

$\mathrm{Na}$ tentativa de se defenderem da agressão policial, os moradores desenvolvem estratégias para se diferenciar dos marginais e não sofrer abusos, como ter cuidado com a aparência pessoal, evitar a circulação em horários e lugares freqüentados por bandidos, manter as luzes das casas apagadas nas ocasiões de batidas policiais, e fazer pressão sobre a polícia, como na situação descrita do negro rastafari, para que ela libere pessoas inocentes presas e agredidas injustamente.

Se os abusos policiais contra populares provocam a condenação enérgica destes, o mesmo não acontece com a violência cometida contra 0 outro, o marginal. Nesse sentido, a maior perversidade do modelo policial consiste no fato de que suas vítimas também são seus defensores.

\section{Bandido é para morrer}

Apesar de serem eles próprios alvo de agressão, os moradores de Novos Alagados aprovam o terror da polícia e grupos de extermínio contra marginais do bairro e áreas próximas do Subúrbio Ferroviário. Esta aprova- 
ção é justificada pela distinção estabelecida por eles, entre a violência ilegítima cometida contra "nós", pessoas direitas, pais de família e trabalhadores honestos, da violência "legítima" que é praticada contra "eles", os marginais.

Pensando dessa maneira, alguns moradores entrevistados consideram a violência policial como algo necessário, e que só atinge as pessoas "erradas" ou que estão em lugares "errados". Joaquim, por exemplo:

Eu sempre me dei bem com a polícia. Porque é o seguinte, eu não faço nada a ela, ela não pode fazer nada a mim. É como eu lhe disse também, as vezes as pessoas ficam em certos lugares inconvenientes e as vezes elas são pegas pela polícia... são até espancadas.

Ainda nessa linha de defesa da violência oficial, Joaquim emprega o mesmo álibi usado pelo policiais para justificar seus excessos, a dificuldade de controlar infratores maliciosos e bem armados, dispostos a revidar ou matar:

Ela [a polícia] vem fazer uma blitz, aí ela sempre, ela já lida com tanta gente maliciosa, que ela tem que quase ser, se tornar igual a pessoa, porque senão morre, você está entendendo onde eu quero chegar, senão ela morre (...) Mas, a maneira como ela chega, ela faz assim como é que se diz, ela acha que todo mundo é um [marginal] não é, então a maneira dela trabalhar é essa, mas aí, eu não sou contra pelo seguinte: eu lhe pergunto, se não existisse a polícia, mesmo com as falhas dela, o que seria da gente? Ela está aí, o camarada faz o que faz, e se ela não existisse?

Conforme uma visão difundida, a violência das autoridades é a resposta à violência dos criminosos, mesmo que os indivíduos e grupos, surpreendidos no fogo cruzado, tenham que pagar um alto preço por isso, perdendo seus direitos ou arriscando a serem tratados do mesmo modo. Concordando com isso, a crítica dos abusos policiais coexiste com sua aprovação. Sobre isso, esclarece Jandira, 17 anos, parda, estudante: 
Muito violenta, ignorante. É polícia, por exemplo, a profissão deles eu sei, é para fazer ignorância, mas não é com as pessoas, é com ladrão! E as vezes matam muitos inocentes, não querem saber de nada, vão logo matando pessoas, eles agem com muita violência, são muito violentos. Vão atirando não é, sei lá. Eu acho uma hora [que] eles estão certos porque ela [a polícia] não quer morrer, se ela vir com mão abanando vai ter ladrão que vai meter bala nela. Aí eu não sei dizer.

O bedecendo ordens ou atuando por conta própria, os policiais atiram sem maiores cuidados e aplicam sentenças de morte contra infratores, suspeitos e pessoas inocentes, sem receberem punição. Q uanto aos meios de comunicação, eles vêm denunciando os abusos policiais e contribuindo para debater a segurança coletiva. Contudo, na falta de ações enérgicas dos poderes públicos, a tendência desse debate é a repetição de motivo, a banalização do inaceitável e confirmação da impotência social para controlar o uso da força policial. U ma ilustração deste uso ilegal da força está contida no depoimento de Claúdio:

Aconteceu uma morte aqui que até hoje não me sai da cabeça. Um cara marginal entrou na casa de uma irmã quando a polícia chegou. Metralharam a casa da mulher toda, mataram todos os filhotes de cachorro [por sinal muito numerosos no bairro], mataram a cadela, esburacaram a televisão, geladeira... o que você imaginar... a sorte foi que não matou os filhos desta mulher porque eles se esconderam debaixo da cama do quarto. Mas mataram o cara, metralharam de toda a forma... assim que terminou amarraram um fio no cara e saíram arrastando lá do fim da ponte até a frente da rua.

Conquanto não questione a ilegalidade do castigo, o morador chama a atenção para a brutalidade do comando policial que, visando matar um marginal acuado, estende a punição a familiares da vítima, violando 0 
domicílio daquela, pondo em perigo a vida de crianças e destruindo símbolos da vida familiar e social, como animais de estimação e utensílios domésticos, cuja reposição sem dúvida sacrificará o geralmente minguado orçamento da vítima.

Se a execução desse bandido e a destruição do cenário doméstico onde ele se refugiou foram acompanhadas por uma platéia aterrorizada e fascinada, existem situações em que as mortes provocadas pelas intervenções policiais acontecem depois da captura e interrogatório violento de suspeitos. Este é o caso de um rapaz que foi preso sob a acusação de estar envolvido com marginais, conduzido ao módulo policial, espancado e assassinado, conforme o testemunho de Juvenal:

Teve um rapaz mesmo em 1984 que não tinha nem muito envolvimento com a marginalidade. Foi preso em uma noite de São João com muitas pessoas vendo e foi espancado até de manhã. Já saiu do módulo policial morto. No outro dia saiu no jornal que a população tinha linchado... [os policiais] fizeram todo tipo de violência e quando chegou no outro dia saiu [nos jornais] que a comunidade havia espancado.

Presenciando ou tomando conhecimento de execuções espetaculares ou discretas, os moradores podem acusar a brutalidade policial, mas não deixam de aprovar o fim daqueles que são julgados irrecuperáveis, que são casos perdidos ou não têm mais remédio. Sobre isso, Maria, 49 anos, branca, costureira, afirma:

Eu acho certo porque se existe pessoas que se metem, que roubam, estupram, cometem crime, são pessoas que devem ser eliminadas (...) prender ou dar fim mesmo, pronto, não mais remédio. Eu sou totalmente contra a violência, mas nesse caso eu sou a favor. 
Tal como em outros planos sociais, a violência aqui é vista como um problema do outro, que a provoca, inflige ou sofre, e não como uma questão que é da responsabilidade de todos. Assim, testemunhando casos que representam a negação das regras do direito e da legalidade que deveriam estabelecer os parâmetros de segurança e proteção para todos, os moradores adotam a perspectiva de apoiar os excessos policiais desde que não sejam dirigidos contra eles. Pensando assim, eles modelam suas atitudes de acordo com as máximas como façam com os outros o que eu não quero que façam comigo ou empreguem a violência para me proteger mas não para me atacar.

Esta irresponsabilidade pela violência decorre do esvaziamento do mundo público, desuso da noção de lei e substituição da compaixão pela crueldade.

\section{Frutos sangrentos}

O aparelho policial adotou, nos últimos vinte anos, uma orientação violenta que, prescindindo de mediações legais, vem causando um alto número de mortes de pessoas predominantemente jovens do sexo masculino, com idade variando entre 15 e 29 anos, pobres, moradores de periferia e negros (Paim, 1996). Ao lado dos homicídios policiais, a atuação dos grupos de extermínio atingiu 104 pessoas, em 1995, e 107 pessoas apenas no primeiro semestre de 1996 (FO RUM de Direitos Humanos quer acabar com grupo de extermínio, 1996).

O número de vítimas eliminadas em cada uma das ações criminosas, segundo matérias veiculadas na imprensa local, variava de uma até cinco pessoas simultaneamente. $0 \mathrm{~s}$ agressores estavam sempre em número superior às vítimas e as chances de sobrevivência destas eram praticamente nulas. 0 sangue frio dos chacinadores estava no fato de que eles tinham um domínio completo sobre os seus condenados. Eles eram os executores de uma sentença prévia e secretamente pronunciada, para a qual não havia apelação ou intermediação (Noronha, 1997). 
As execuções eliminam lideranças e produzem revolta entre os sobreviventes das quadrilhas, que aumentam as agressões contra moradores desprotegidos. 0 fim de uma liderança também é acompanhado por ajustes de contas e lutas sucessórias sangrentas, que desorganizam o controle dos delinqüentes sobre o bairro e tornam os moradores vulneráveis à ação de outras quadrilhas que, não encontrando resistência local, invadem o território dantes monopolizado por eles.

Acima de tudo, as mortes logram a redução temporária do ritmo de atividade das quadrilhas, mas são incapazes de evitar que outros jovens, seduzidos pela marginalidade e, inclusive, estimulados por policiais infratores e outros agenciadores do crime, trilhem o caminho dos que foram eliminados.

A morte de infratores, suspeitos e até inocentes levanta a questão do que fazer com os seus corpos, em especial, quando as mortes acontecem nos bairros populares. Chama atenção a demora dos órgãos públicos para recolher os cadáveres, que costumam ficar ao relento durante longos períodos - que variam de algumas horas até um dia inteiro -, sendo vistos, apresentando sinais de decomposição e exalando odores que incomodam a todos. Conforme Pedro todo mundo sabe que é um absurdo, por ser um lugar já sujo [com lixo acumulado e esgotos a céu aberto] e se chegar uma pessoa de fora vê, o mau cheiro, o corpo no sol quente, a barriga perto de estourar.

Para o mesmo cidadão, esse tratamento dado aos mortos não é diferente do que é ministrado às pessoas vivas que residem no bairro, pois em área pobre não tem pressa nenhuma de pegar o corpo, ainda mais vagabundo ... vamos deixar lá para o pessoal tomar exemplo. Já para outro morador, O smar, 55 anos, pardo, trabalhador aposentado, a exposição dos cadáveres é conseqüente com o tratamento que deve ser dado aos marginais: ah, morte de vagabundo fica mofando aí, quando vem apanhar [os órgãos responsáveis] está até fedendo, todo mundo apoia a morte deles, morreu fica aí.

Ainda que aprove 0 terror policial, O smar aponta a inconveniência das execuções públicas e exposições dos cadáveres das vítimas, chegando a declarar que prefere que estas sejam mortas fora do bairro para preservar 
as crianças e jovens dessas visões: não deveriam matar os vagabundos no bairro, é muito feio... as crianças vêem... fica como espelho e isso é ruim para a crianças... eles [os policiais] matam na frente das pessoas mesmo ... eles deviam levar para outro lugar [e lá] a polícia dava um jeito.

Esta prática já é adotada por muitos policiais e integrantes de grupos de extermínio, que executam as suas vítimas em locais isolados, não para preservar a população das sinistras cenas, mas para ocultar a autoria das mesmas. Com esta preocupação, os algozes costumam recolher os documentos, mutilar ou queimar os corpos das vítimas para dificultar sua identificação.

Enfim, a política da "solução final" evidencia um proceder que ataca sintomas da crise social, mas não enfrenta as suas causas. Agindo no vazio criado pela falta de políticas de promoção social e crise do sistema penal (Pegoraro, 2000), o terror policial é um agravante da situação ou, no dizer popular, "o barato que sai caro".

\section{Conclusões}

$\mathrm{Na}$ discussão sobre o modelo policial, examinaram-se suas relações com segmentos excluídos e discriminados da sociedade. Em vez de analisar a violência policial como um fato que vem de cima ou é imposto de fora, contra a vontade dos indivíduos e grupos sobre os quais ela recai, preferiu-se discutir as condições de possibilidade que tornam certos abusos plausíveis e aceitáveis para muitos e, inclusive, para suas vítimas. Vista dessa maneira, a arbitrariedade policial não é um aspecto isolado, mas é parte de um sistema que, abrangendo autoridades e cidadãos, coloca o combate da criminalidade acima da aplicação da lei e proteção da sociedade.

Se, do ponto de vista oficial, a violência é um meio fácil de resolver os problemas da criminalidade, a população não demonstra recusar este meio. Para os moradores das áreas urbanas periféricas, nas quais são falhos 
os mecanismos de controle informal, a delinqüência é endêmica e inexiste policiamento efetivo, as medidas violentas, da polícia ou de grupos de extermínio, são concebidas como um meio de proteção contra a insegurança. Testemunhando uma violência que é a negação do Direito, estes segmentos apóiam os abusos policiais que não sejam dirigidos contra eles.

Entretanto, como a violência policial tem uma dinâmica própria, fundada em concepções e políticas social e racialmente discriminatórias, é inevitável que pessoas comuns, inocentes sejam objeto da brutalidade policial, que não se justifica mesmo contra os chamados "marginais". Para estes, existe a lei, que devia existir também para o policial que mata sem motivo legítimo, que humilha, agride, espanca, tortura.

Conquanto se tenha muitos indícios sobre ações bem sucedidas de resistência, em que grupos de moradores se organizaram para pressionar comandos policiais e obter medidas concretas contra praticantes de abusos, estas iniciativas são localizadas, não tendo logrado até aqui se generalizar para o conjunto da cidade.

Um programa de controle da violência deve estar direcionado para suas causas e conseqüências. Entre as principais medidas está a promoção racial (Guimarães, 1996), sociocultural, econômica e educacional da juventude destituída da cidade, ampliando e reformulando os programas já existentes em órgãos governamentais e não-governamentais, assim como mobilizando a energia das comunidades envolvidas e oferecendo meios de realização do seu potencial criativo.

Acima de tudo, as comunidades, através de grupos de vizinhos, associações, grupos negros, movimentos culturais, sindicatos e outros, precisam mobilizar-se para dar um basta a isso. Ao lado das reivindicações de melhorias materiais, é chegado o momento de as comunidades passarem a se preocupar com a criação de meios justos e efetivos de promover a segurança da cidadania. 
Sociologias, Porto Alegre, ano 4, № 7, jan/jun 2002, p. 188-221

\section{Referências bibliográficas}

CARVALHO FRANCO, Maria Silvia. Homens livres na ordem escravocrata. São Paulo: Kairós, 1983.

CASTEL, Roberto. As metamorfoses da questão social. Petrópolis: Vozes, 1995.

CEDEC. M apa de risco da violência: Salvador. São Paulo: Cedec, 1997.

CHEVIGNY, Paul. Edge of the knife: police violence in the Americas. New York: The N ew Press, 1995.

DaMATTA, Roberto. Os discursos da violência no Brasil. In: DaM ATTA, Roberto. Conta de mentiroso. Rio de Janeiro: Rocco, 1993.

ELIAS, Norbert. O processo civilizador. Rio de Janeiro: Jorge Zahar, 1994.

FO RUM de Direitos Humanos quer acabar com crimes de extermínio. A Tarde, Salvador: 14 maio, 1996.

GAY, Peter. O cultivo do ódio. São Paulo: Companhia das Letras, 1995.

GABALDÓ N, Luis G.; BIRBECK, Christopher. Investigación exploratoria sobre la disposición de agentes policiales de usar la fuerza contra el ciudadano. Reunión Grupo Violencia y Sociedad, Caracas: n.1,2000, p.1-20.

GU IM ARÃES, Antônio S. A Políticas para a ascensão dos negros no Brasil. AfroÁsia, Salvador: v.18, 1996, p.235-261.

GUIMARÃES DA SILVA, Paulo R.; PENTEADO SILVA, Paulo A. Projeto integrado de pesquisa: meio ambiente urbano e qualidade de vida em Salvador. NPGAUFBA, 1996.

M IN AYO, Maria Cecília et alii. Violência para todos. Caderno de Saúde Pública, Rio de Janeiro: v.7, 1993, p.215-231.

NO RO NHA, Ceci Vilar; PAES M ACH ADO, Eduardo et alii. Projeto Activa: atitudes e normas culturais frente à violência em cidades selecionadas da região das Américas. Salvado: OPAS/U FBA/UNEB, 1997. 
NORONHA, Ceci Vilar. Mortes violentas na Região Metropolitana de Salvador. Salvador: ISC/U FBA, 1966 (mimeo).

PAES M ACH AD O , Eduardo; CARDO SO , Fátima Cardoso. Ambiente urbano e mobilidade social na beira do mar. Cademos do CEAS. Salvador: v.163, 1996, p.64-80.

PAES M ACH ADO , Eduardo; TAPPARELLI, Gino Tapparelli. Violência juvenil, infração e morte nas quadrilhas de Salvador. Cademosdo CEAS. Salvador: v.165, 1996, p.63-81.

PAIM, Jairnilson Silva; COSTA, Maria C. N. et alii. Mortes violentas em crianças e adolescentes de Salvador. Bahia, Análise e Dados. Salvador: v.6, n.1, 1996, p.59-67.

PEGO RARO, Juan S. Las políticas de seguridad y la participaciön comunitaria en el marco de violencia social. Reunión Grupo Violencia y Sociedad de Clacso . Caracas: n.1, 2000, p.1-28.

PINHEIRO, Paulo Sérgio. Crime, violência e poder. São Paulo: Brasiliense, 1983.

ZALU AR, Alba. Condomínio do diabo. Rio de Janeiro: Revan-U FRJ, 1994.

\section{Resumo}

0 artigo discute a violência policial do ponto de vista dos segmentos sociais mais atingidos pela mesma, trabalhado res pobres, negro-mestiços e moradores de Novos Alagados, uma das áreas carentes da cidade de Salvador. Através de 31 entrevistas aprofundadas e uso de técnicas de observação direta, procurou-se reconstituir os tipos de violência protagonizados por moradores, delinqüentes e policiais. Num contexto de pobreza, desemprego e crise dos mecanismos informais de controle so cial, o aparelho policial gera reações ambivalentes que expressam a dificuldade de a população se posicionar diante de uma força que é vista como violenta e, ao mesmo tempo, protetora. Condenando os abusos policiais contra eles, mas defendendo-os contra indivíduos tidos como marginais, os moradores terminam por legitimar a brutalidade contida no modelo de policiamento.

Palavras-chave: controle social, pobreza, polícia, violência. 